\title{
4,5-Disubstituted N-Aminoimdazol-2-One Mimics of Peptide Turn Backbone and Side Chain Conformation
}

\author{
Julien Poupart, Duc Doan-Ngoc, and William D. Lubell \\ Department of chemistry, Université de Montréal, Montreal, Canada
}

\section{Introduction: $\mathrm{N}$-aminoimdazol-2-one (Nai) residues}

Nai residues have been shown by NMR spectroscopy and X-ray crystallography to adopt turn conformations, and have been incorporated into biologically active peptides to study structure-activity relationships (Figure 1) [1,2]. The synthesis of Nai residues has entailed alkylation of aza-glycinyl dipeptides with propargyl bromide using tetraethyl ammonium hydroxide, followed by sodium hydride

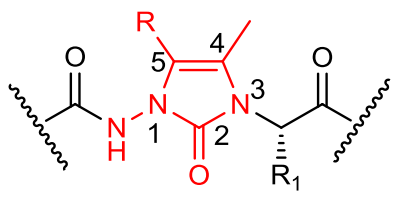

A<smiles>[X]c1c(C)n(C(Cc2ccccc2)[C@@H](NC(=O)c2ccc(OC)cc2)C(=O)NC(C)C)c(=O)n1NC(=O)c1ccc(O)cc1</smiles>
B

Fig. 1. 4,5-disubstituted Nai residue in a peptide $(A)$ and model Nai peptide 1 (B). induced 5-exo-dig cyclisation and exo-to endo-alkene epimerization. By performing a Sonogashira reaction on the aza-propargylglycine residue prior to ring formation, various aromatic and heteroaromatic ring systems have been introduced at the 4-position of the aminoimdazol-2-one residue. Although the use of strong base led to epimerization of aza-glycinyl dipeptide $C$-terminal $\alpha$-amino esters, the Nai dipeptide enantiomers were effectively separated by chiral supercritical fluid chromatography [3]. After liberation of the carboxylic acid, the resulting Nai dipeptide building blocks have been inserted into longer peptide structures by standard coupling methods $[1,2]$.

The current method for Nai peptide construction offers effective means for introducing substituents at the 4-position to mimic different amino acid side chains. Moreover, the 4-position substituents have been observed by crystallographic analyses to influence the conformation of the $C$-terminal $\alpha$-amino acid residue side chain in model Nai peptides [2]. Considering the natural orientation of amino acid side chains in chi-space [4], the Nai 5-position represents a promising location for the attachment of substituents for peptide mimicry [5]. Evidence that the backbone and side chain geometry of natural amino acids involved in $\beta$-turns may be mimicked by 5-aryl Nai residues was derived from molecular modelling using HyperChem $8^{\mathrm{TM}}$, which predicted that model Nai peptide 1 adopted a type II' $\beta$-turn conformation in which the aromatic side chain $\chi^{1}$ torsion angle was oriented in a gauche $(-)$ conformation (Figure 1).

Aromatic residues are abundant at the central positions of turn conformations of naturally occurring bioactive peptides, such as somatostatin [6]. Constrained mimics of aryl amino acids that adopt turn conformations may thus offer interesting potential for studying structure-activity relationships [7]. Arylation of the Nai 5-position is thus being studied to provide rigidified aryl and heteroarylalanine residues for turn mimicry.

\section{Results and Discussion}

Palladium catalyzed arylation was performed in solution on a protected Nai analog to functionalize the 5-position. For example, employing Nai dipeptide 2 [1], the palladium-catalyzed arylation with 4-iodophenyl-4-methylbenzenesulfonate gave 5-aryl Nai dipeptide 3 in $86 \%$ yield (Figure 2). In the interest of studying the conformation of the 5-aryl Nai residue, efforts are now being pursued to incorporate Nai dipeptide 3 into model peptides as a constrained aza-tyrosine surrogate. Moreover, the scope of the palladium-catalyzed arylation will be explored to assess its tolerance to different functionalities on both the alkene and aryl iodine. 
<smiles>CCOC(=O)[C@@H](Cc1ccccc1)n1c(C)cn(N=C(c2ccccc2)c2ccccc2)c1=O</smiles>
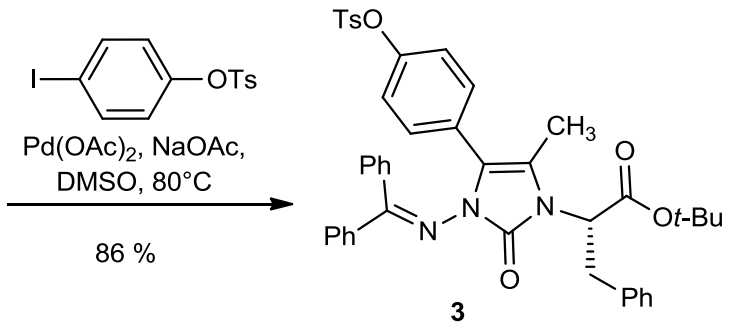

Fig. 2. Synthesis of $\mathbf{3}$.

(S)-tert-butyl 2-\{3-[(diphenylmethylene)amino]-5-methyl-2-oxo-4-[4-(tosyloxy)phenyl]-2,3-dihydro1H-imidazol-1-yl\}-3-phenylpropanoate (3)

tert-Butyl (2R)-2-\{3-[(diphenylmethylidene)amino]-5-methyl-2-oxo-2,3-dihydro-1H-imidazol-1-yl $\}$ 3 -phenylpropanoate (1 eq., $67 \mathrm{mg}, 0.14 \mathrm{mmol}$, prepared according to reference 8), 4-iodophenyl 4methylbenzene-1-sulfonate ( 3 eq., $156 \mathrm{mg}, 0.42 \mathrm{mmol}$, prepared according to reference 9), sodium acetate (3 eq., $34 \mathrm{mg}, 0.42 \mathrm{mmol}$ ) and palladium acetate $(10 \mathrm{~mol} \%, 3 \mathrm{mg}, 0.014 \mathrm{mmol})$ were dissolved in degassed DMSO $(1 \mathrm{~mL})$ in a pressure vessel. The vessel was purged with argon, heated to $80^{\circ} \mathrm{C}$, and stirred overnight, when complete reaction was observed by TLC (disappearance of starting material, Rf $0.45,30 \%$ EtOAc/Hexanes). The reaction mixture was partitioned between DCM (10 mL) and a mixture of brine $(8 \mathrm{~mL})$ and $5 \%$ citric acid $(2 \mathrm{~mL})$. The phases were separated and the organic layer was washed with brine $(3 \times 5 \mathrm{~mL})$. The combined organic phases were dried over magnesium sulfate, filtered and evaporated to a residue that was purified by column chromatography on silica gel using 15-30\% EtOAc in hexanes as eluent. Evaporation of the collected fractions gave 5-aryl Nai $\mathbf{3}$ as a yellow oil $(87 \mathrm{mg}, 86 \%): \mathrm{R}_{\mathrm{f}} 0.34\left(30 \%\right.$ EtOAc / hexanes); ${ }^{1} \mathrm{H} \mathrm{NMR}\left(400 \mathrm{MHz}, \mathrm{CDCl}_{3}\right) \delta 1.49(9 \mathrm{H}$, s), $1.61(3 \mathrm{H}, \mathrm{s}), 2.40(3 \mathrm{H}, \mathrm{s}), 3.39-3.43(2 \mathrm{H}, \mathrm{m}), 4.64-4.68(1 \mathrm{H}, \mathrm{m}), 6.81-6.92(5 \mathrm{H}, \mathrm{m}), 7.00-7.02(2 \mathrm{H}$, $\mathrm{m}), 7.13(2 \mathrm{H}, \mathrm{d}, J=8 \mathrm{~Hz}), 7.18-7.22(5 \mathrm{H}, \mathrm{m}), 7.34-7.39(3 \mathrm{H}, \mathrm{m}), 7.45-7.49(2 \mathrm{H}, \mathrm{m}), 7.54(2 \mathrm{H}, \mathrm{d}, J=$ $8 \mathrm{~Hz}), 7.63(2 \mathrm{H}, \mathrm{d}, J=8 \mathrm{~Hz}) .{ }^{13} \mathrm{C}$ NMR $\left(75 \mathrm{MHz}, \mathrm{CDCl}_{3}\right) \delta 174.6,168.4,148.3,148.1,145.4,137.8$, 137.1, 135.0, 132.2, 131.2, 130.1, 129.7, 129.6, 129,2, 128.7, 128.4, 128.0, 127.8, 126.6, 122.1, 117.8, 116.1, 82.4, 57.6, 35.4, 29.7, 28.0, 21.7, 9.5. HRMS Calcd. $\left(\mathrm{C}_{43} \mathrm{H}_{42} \mathrm{~N}_{3} \mathrm{O}_{6} \mathrm{~S}\right)^{+}=728.2789$, found $=$ $728.2802(\mathrm{M}+\mathrm{H})^{+}$.

\section{Acknowledgments}

The authors would like to thank the Natural Sciences and Engineering Research Council of Canada (NSERC), the Canadian Institutes of Health Research (CIHR), the Ministère du développement économique de l'innovation et de l'exportation du Quebec (\#878-2012, Traitement de la dégénerescence maculaire), Amorchem and the NSERC Collaborative Research and Training Experience Program (CREATE) in Continuous Flow Science.

\section{References}

1. Proulx, C., Lubell, W.D. Biopolymers, Pep. Sci. 102, 7-15 (2014), http://dx.doi.org/10.1002/bip.22327

2. Proulx, C., Lubell, W.D. Org. Lett. 14, $4552-4555$ (2012), http://dx.doi.org/10.1021/ol302021n

3. García-Ramos, Y., Proulx, C., Camy, C., Lubell, W.D., in G. Kokotos, V. Constantinou-Kokotou, J.

Matsoukas (Editors), Proceedings of the 32nd Europ. Peptide Symp., European Peptide Society, 2012, pp. 366-367.

4. Hruby, V.J., Li, G., Haskell-Luevano, C., Shenderovich, M. Peptide Science 43, 219-266 (1997), http://dx.doi.org/10.1002/(SICI)1097-0282(1997)43:3<219::AID-BIP3>3.0.CO;2-Y

5. Doan, N.D., Hopewell, R., Lubell, W.D. Org. Lett. 16, 2232-2235 (2014), http://dx.doi.org/10.1021/o1500739k

6. Mattern, R.H., Tran, T.A., Goodman, M. J. Pept. Sci. 5, 161-175 (1999), http://dx.doi.org/10.1002/(SICI)1099-1387(199904)5:4<161::AID-PSC177>3.0.CO;2-F

7. Makwana, K.M., Mahalakshmi, R. Org. Biomol. Chem. 12, 2053-2061 (2014), http://dx.doi.org/10.1039/C3OB42247J 